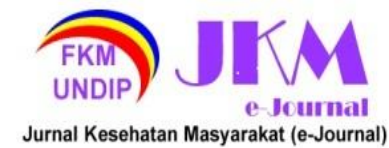

JURNAL KESEHATAN MASYARAKAT (e-Journal)

Volume 9, Nomor 5, September 2021

ISSN: 2715-5617 / e-ISSN: 2356-3346

http://ejournal3.undip.ac.id/index.php/jkm

\title{
HUBUNGAN PRAKTIK KEBERSIHAN PERORANGAN KARYAWAN DAN KONDISI LINGKUNGAN KERJA DENGAN KEJADIAN TERINFEKSI COVID-19 DI PT X JAKARTA BARAT
}

\author{
Evelyn Sri Wulandari ${ }^{*}$, Tri Joko ${ }^{2}$, Suhartono ${ }^{2}$ \\ ${ }^{1}$ Peminatan Kesehatan Lingkungan, Fakultas Kesehatan Masyarakat Universitas Diponegoro \\ ${ }^{2}$ Bagian Kesehatan Lingkungan, Fakultas Kesehatan Masyarakat Universitas Diponegoro \\ ${ }^{*}$ Corresponding author: Iynvarine@gmail.com
}

\begin{abstract}
ABSTRAK
COVID-19 merupakan penyakit infeksi saluran pernafasan akut, diakibatkan oleh novel coronavirus. Penularan COVID-19 terjadi lewat 3 jalan utama, yakni kontak langsung, droplet serta aerosol. Sektor perkantoran ialah salah satu klaster penularan COVID-19, Area perkantoran cenderung padat oleh manusia, oleh sebab itu kondisi lingkungan kerja butuh diperhatikan dalam penangkalan COVID-19. Belum ditemukan obat untuk mengobati COVID-19, akan tetapi penularan COVID-19 bisa dicegah lewat beberapa metode, salah satunya menerapkan praktik kebersihan perorangan. Penelitian ini bertujuan untuk mengetahui hubungan antara kebersihan perorangan karyawan dan kondisi lingkungan kerja dengan kejadian terinfeksi COVID-19 di PT X Jakarta Barat. Jenis penelitian ini adalah kuantitatif dengan pendekatan cross sectional. Sampel penelitian ini yakni 60 karyawan di PT $X$ Jakarta Barat. Metode pengambilan sampel yang digunakan dalam penelitian ini yakni sampling acak. Analisis bivariat menggunakan uji chi-square Data diambil menggunakan kuesioner penelitian. Hasil uji chi-square menunjukkan bahwa terdapat hubungan antara praktik kebersihan perorangan karyawan dengan praktik penggunaan masker $(0,016)$, praktik cuci tangan pakai sabun $(0,016)$ dan tidak terdapat hubungan antara praktik kebersihan perorangan karyawan dengan praktik menjaga jarak (0,315), praktik tidak menyentuh wajah sebelum mencuci tangan (1) dan kondisi lingkungan kerja $(0,55)$. Ada hubungan yang signifikan antara praktik penggunaan masker dan praktik cuci tangan pakai sabun dengan kejadian COVID-19. Para karyawan disarankan untuk tetap melakukan praktik kebersihan perorangan sesuai anjuran selama bekerja.
\end{abstract}

\section{Kata Kunci : COVID-19, perkantoran, personal hygiene, kondisi lingkungan kerja}

\section{PENDAHULUAN}

Pada akhir tahun 2019 menuju awal tahun 2020, dunia mengalami pandemi, dimulai dengan merebaknya kasus pneumonia yang belum diketahui asalnya, teridentifikasi di Wuhan, Provinsi Hubei, Tiongkok. Patogen penyebabnya diidentifikasi sebagai novel coronavirus yang termasuk dalam genus Beta Coronavirus. Kemudian penyakit ini dinamakan severe acute respiratory syndrome coronavirus 2 (SARS-CoV-2) oleh Komite Taksonomi Virus.(1)

Gejala COVID-19 yang paling sering ditemui adalah demam dengan suhu diatas 38 derajat celcius, batuk dan kelelahan. Gejala lain yang terjadi pada kondisi lebih berat adalah munculnya dahak, sakit kepala, batuk darah, sesak nafas dan turunnya jumlah leukosit (limfopenia). ${ }^{(2)}$

Perubahan indera penciuman (anosmia) atau indera perasa (hypogeusia) juga dikategorikan dalam gejala awal COVID19 walaupun tidak terjadi gejala lain. Walaupun relevansi klinis pada gejala ini masih belum ditetapkan, gejala ini sudah ditambahkan kedalam daftar indikasi COVID19 yang dimana jika seseorang mengalami gejala ini harus segera melakukan uji COVID19 dan isolasi mandiri di Inggris. ${ }^{(3)}$

Penularan COVID-19 dapat terjadi melalui 3 jalur utama, yaitu melalui kontak langsung, aerosol dan droplet. Penularan melalui kontak langsung dapat terjadi jika terdapat kontak langsung dengan objek atau permukaan yang terinfeksi virus dan akan menginfeksi manusia melalui mulut, hidung atau mata. Penularan jenis ini banyak terjadi pada tenaga kesehatan yang melakukan kontak langsung dengan pasien COVID-19. Penularan COVID-19 dapat dicegah dengan menerapkan kebersihan perorangan/personal hygiene seperti mencuci tangan dengan sabun atau hand rub yang mengandung alcohol secara berkala dan menghindari menyentuh mata, hidung dan mulut. ${ }^{(4)}$

Penularan juga dapat terjadi melalui aerosol. Meskipun virus penyebab COVID-19 bukan merupakan airborne virus, aerosol dari sisa batuk dan bersin penderita COVID-19 dapat hidup di udara selama 3 jam. Ruangan yang tertutup tanpa sirkulasi udara yang baik dapat meningkatkan kemungkinan penularan. Terakhir, penularan melalui droplet. Udara yang digunakan untuk bernafas normalnya mengandung banyak droplet dengan ukuran 


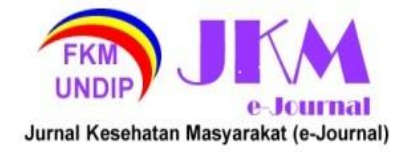

diameter kurang dari 5 mikrometer. Batuk dan bersin dapat meningkatkan keluarnya droplet yang berasal dari rongga mulut dan saluran pernafasan. Jika droplet dari penderita COVID-19 terhirup, tertelan atau mengenai membran mucus seseorang, maka orang tersebut akan tertular penyakit ini.(5)

Klaster Perkantoran termasuk penyumbang terbesar total kasus COVID-19. Hal ini dapat dikarenakan area perkantoran yang cenderung bekerja secara tim, sehingga dalam penerapan physical distancing kurang maksimal. Perkantoran pada umumnya juga merupakan ruangan tertutup yang meningkatkan resiko penularan COVID-19 melalui aerosol. Selain itu, karyawan yang bekerja di kantor juga memiliki resiko terinfeksi COVID-19 saat perjalanan menuju kantor, terutama karyawan yang menaiki kendaraan umum. Sehubungan dengan belum ditemukannya obat untuk menyembuhkan COVID-19, pencegahan berupa upaya kebersihan perorangan menjadi salah satu cara untuk mencegah penularan COVID-19 di wilayah perkantoran. Penelitian ini bertujuan untuk menganalisis hubungan antara upaya kebersihan perorangan karyawan dan kondisi lingkungan kerja dengan kejadian terinfeksi COVID-19 di PT X Jakarta Barat.

\section{METODE PENELITIAN}

Penelitian ini termasuk dalam jenis penelitian kuantitaitf dengan pendekatan cross-sectional. Populasi pada penelitian ini adalah karyawan PT $X$ Jakarta Barat. Besar sampel dihitung menggunakan rumus slovin dan didapatkan sampel sebesar 60 karyawan. Teknik sampling yang digunakan adalah Nonprobability Sampling yaitu Accidental Sampling dengan cara mengambil 60 responden secara acak. Sampling dilakukan selama 3 hari, dengan rincian 20 responden pada hari pertama, 20 responden pada hari kedua dan 20 responden pada hari ketiga. Instrumen yang digunakan dalam pengumpulan data berupa kuesioner dengan rincian pada variabel penggunaan masker terdapat 6 butir pertanyaan, pada variabel cuci tangan pakai sabun terdapat 6 butir pertanyaan, pada variabel menjaga jarak terdapat 5 butir pertanyaan, pada variabel tidak menyentuh wajah sebelum mencuci tangan terdapat 3 butir pertanyaan dan pada variabel kondisi lingkungan kerja terdapat 5 butir pertanyaan. Skoring dilakukan dengan memberi skor 0 pada jawaban yang tidak sesuai anjuran dan 1 pada jawaban yang sesuai anjuran. Skor pada setiap variabel dijumlah dan dicari nilai median. Cut off point pengkategorian menggunakan nilai median. Pada variabel penggunaan masker didapatkan nilai median 3 . Jika total skor pada variabel penggunaan masker $\geq 3$, dikategorikan aman dan jika total skor $<3$, dikategorikan tidak aman. Pada variabel cuci tangan pakai sabun, didapatkan nilai median 6 . Jika total skor pada variabel cuci tangan pakai sabun $\geq 6$, dikategorikan baik dan jika total skor $<6$, dikategorikan kurang baik. Pada variabel menjaga jarak, didapatkan nilai median 5. Jika total skor pada variabel menjaga jarak $\geq 5$, dikategorikan baik dan jika total skor $<5$, dikategorikan kurang baik. Pada variabel tidak menyentuh wajah sebelum mencuci tangan, didapatkan nilai median 2. Jika total skor pada variabel tidak menyentuh wajah sebelum mencuci tangan $\geq 2$, dikategorikan baik dan jika $<2$, dikategorikan kurang baik. Pada variabel kondisi lingkungan kerja, didapatkan nilai median 5. Jika total skor pada variabel kondisi lingkungan kerja $\geq 5$, dikategorikan baik dan jika total skor $<5$, dikategorikan kurang baik. Analisis yang digunakan dalam menganalisis data ialah analisis univariat dan bivariat. Analisis bivariat menggunakan chisquare untuk mengetahui hubungan antara variabel bebas dan variabel terikat dengan taraf signifikan $5 \%$ dan derajat kepercayaan $95 \%$. Jika $p$-value $\leq 0,05$, artinya terdapat hubungan antar variabel bebas dan terikat. Jika $p$-value $>0,05$, artinya tidak terdapat hubungan antar variabel bebas dan terikat.

\section{HASIL DAN PEMBAHASAN}

Hasil dari penelitian ini terdiri dari hasil analisis univariat, yakni distribusi responden pada setiap variabel dan hasil analisis bivariat, yakni hubungan antara variabel bebas dan variabel terikat.

\section{Hasil Analisis Univariat}

Analisis univariat pada penelitian ini dilakukan untuk mengetahui distribusi frekuensi responden dan nilai median pada setiap variabel. Hasil dari analisis univariat pada setiap variabel adalah sebagai berikut.

Berdasarkan hasil penelitian yang telah dilaksanakan, didapatkan distribusi frekuensi praktik penggunaan masker karyawan di PT X (Tabel 1)

Tabel 1. Distribusi Responden Menurut Praktik Penggunaan Masker

\begin{tabular}{cccc}
\hline No & Masker & Frekuensi & $\begin{array}{c}\text { Persentase } \\
(\%)\end{array}$ \\
\hline 1 & Tidak & 16 & 26,7 \\
& aman & & \\
\hline
\end{tabular}




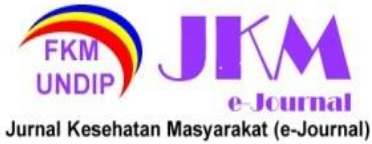

2

$\begin{array}{ccc}\text { Aman } & 44 & 73,3 \\ \text { Jumlah } & 60 & 100\end{array}$

Tabel 1 menunjukkan sebanyak 16 $(26,7 \%)$ karyawan memiliki praktik penggunaan masker yang tidak aman dan sebanyak $44 \quad(73,3 \%)$ karyawan memiliki praktik penggunaan masker yang aman. Didapatkan nilai median sebesar 3.

Berdasarkan hasil penelitian yang telah dilaksanakan, didapatkan distribusi frekuensi praktik cuci tangan pakai sabun karyawan di PT X (Tabel 2)

Tabel 2. Distribusi Responden Menurut Praktik Cuci Tangan Pakai Sabun

\begin{tabular}{llll}
\hline No & CTPS & Frekuensi & Persentase \\
\hline 1 & Kurang & 5 & 8,3 \\
& Baik & & \\
2 & Baik & 55 & 91,7 \\
& Jumlah & 60 & 100,0 \\
\hline
\end{tabular}

Tabel 2 menunjukkan sebanyak 5 $(8,3 \%)$ karyawan memiliki praktik cuci tangan pakai sabun yang kurang baik dan sebanyak $55(91,7 \%)$ karyawan memiliki praktik cuci tangan pakai sabun yang aman. Didapatkan nilai median sebesar 6 .

Berdasarkan hasil penelitian yang telah dilaksanakan, didapatkan distribusi frekuensi praktik menjaga jarak karyawan di PT X (Tabel 3)

Tabel 3. Distribusi Responden Menurut Praktik Menjaga Jarak

\begin{tabular}{llll}
\hline No & $\begin{array}{l}\text { Jaga } \\
\text { Jarak }\end{array}$ & Frekuensi & Persentase \\
\hline 1 & Kurang & 7 & 11,7 \\
& Baik & & \\
2 & Baik & 53 & 88,3 \\
& Jumlah & 60 & 100 \\
\hline
\end{tabular}

Tabel 3 menunjukkan sebanyak 7 $(11,7 \%)$ karyawan memiliki praktik menjaga jarak yang kurang baik dan sebanyak 53 $(88,3 \%)$ karyawan memiliki praktik menjaga jarak yang baik. Didapatkan nilai median sebesar 5.

Berdasarkan hasil penelitian yang telah dilaksanakan, didapatkan distribusi frekuensi

\author{
Volume 9, Nomor 5, September 2021 \\ ISSN: 2715-5617 / e-ISSN: 2356-3346 \\ http://ejournal3.undip.ac.id/index.php/jkm
}

praktik tidak menyentuh wajah sebelum mencuci tangan karyawan di PT X (Tabel 4)

Tabel 4. Distribusi Responden Menurut Praktik Tidak Menyentuh Wajah Sebelum Mencuci Tangan

\begin{tabular}{llll}
\hline No & $\begin{array}{l}\text { Menyentuh } \\
\text { Wajah }\end{array}$ & Frekuensi & Persentase \\
\hline 1 & Kurang Baik & 2 & 3,3 \\
2 & Baik & 58 & 96,7 \\
& Jumlah & 60 & 100 \\
\hline
\end{tabular}

Tabel 4 menunjukkan sebanyak 2 $(3,3 \%)$ karyawan memiliki praktik tidak menyentuh wajah sebelum mencuci tangan kurang baik dan sebanyak $58 \quad(96,7 \%)$ karyawan memiliki praktik tidak menyentuh wajah sebelum mencuci tangan yang baik. Didapatkan nilai median sebesar 2.

Berdasarkan hasil penelitian yang telah dilaksanakan, didapatkan distribusi frekuensi kondisi lingkungan kerja karyawan di PT $\mathrm{X}$ (Tabel 5)

Tabel 5. Distribusi Responden Menurut Kondisi Lingkungan Kerja

\begin{tabular}{llll}
\hline No & $\begin{array}{l}\text { Kondisi } \\
\text { Lingkungan } \\
\text { Kerja }\end{array}$ & Frekuensi & Persentase \\
\hline 1 & Kurang Baik & 24 & \\
2 & Baik & 36 & 60 \\
& Jumlah & 60 & 100 \\
\hline
\end{tabular}

Tabel 5 menunjukkan sebanyak 24 (40\%) karyawan memiliki kondisi lingkungan kerja yang kurang baik dan sebanyak 36 $(60 \%)$ karyawan memiliki kondisi lingkungan kerja yang baik. Didapatkan nilai median sebesar 5 .

\section{Hasil Analisis Bivariat}

Analisis bivariat pada penelitian ini dilakukan untuk mengetahui hubungan antara variabel bebas dan variabel terikat. Analisis bivariat pada penelitian ini menggunakan uji chi-square.

Berdasarkan pengujian hubungan antara variabel praktik penggunaan masker dengan variabel kejadian COVID-19 menggunakan uji chi square, didapatkan hasil sebagai berikut (Tabel 6). 


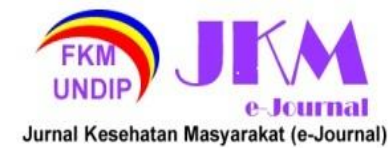

JURNAL KESEHATAN MASYARAKAT (e-Journal)

Volume 9, Nomor 5, September 2021

ISSN: 2715-5617 / e-ISSN: 2356-3346

http://ejournal3.undip.ac.id/index.php/jkm

Tabel 6. Hubungan antara Praktik Penggunaan Masker Karyawan dengan Kejadian Terinfeksi COVID-19

\begin{tabular}{|c|c|c|c|c|c|c|c|c|}
\hline \multirow{3}{*}{$\begin{array}{l}\text { Praktik } \\
\text { Masker }\end{array}$} & \multirow[t]{3}{*}{ Penggunaan } & \multicolumn{5}{|c|}{ Kejadian COVID-19 } & \multirow{3}{*}{$\begin{array}{c}\text { Nilai } \\
p\end{array}$} & \multirow{3}{*}{$\begin{array}{c}\mathbf{R P} \\
(95 \% \\
\mathbf{C l})\end{array}$} \\
\hline & & \multicolumn{2}{|c|}{ Positif } & \multicolumn{2}{|c|}{ Negatif } & \multirow[t]{2}{*}{ Total } & & \\
\hline & & $\mathbf{N}$ & $\%$ & $\mathbf{N}$ & $\%$ & & & \\
\hline Tidak Aman & & 3 & 18,75 & 13 & 81,25 & 16 & 0,016 & 0,813 \\
\hline Aman & & 0 & 0 & 44 & 100 & 44 & & $(0,64-$ \\
\hline
\end{tabular}

\begin{tabular}{lllll}
\hline Total & & & $1,02)$ \\
\hline
\end{tabular}

Berdasarkan hasil uji statistik antara variabel praktik penggunaan masker dan kejadian terinfeksi COVID-19 diperoleh pvalue $=0,016$ artinya ada hubungan antara praktik penggunaan masker karyawan dan kejadian terinfeksi COVID-19. Nilai $\mathrm{Cl} 0,813$ yang berarti karyawan yang menggunakan masker dengan tidak aman memiliki peluang resiko tidak terinfeksi COVID-19 0,813 kali lebih kecil dibanding karyawan dengan praktik penggunaan masker yang aman.

Hasil ini sehubungan dengan penelitian Yanni $\mathrm{Li}$ (6) yang membuktikan bahwa menggunakan masker dapat menurunkan resiko tertular COVID-19, dikarenakan masker dapat mencegah inhalasi droplet. Dari hasil

penelitian praktik penggunaan masker pada karyawan di PT $X$ Jakarta Barat, dapat dikatakan masih terdapat karyawan yang tidak menggunakan masker secara aman, terutama dalam hal jenis masker yang digunakan sehari-hari. Mayoritas karyawan masih menggunakan masker kain yang dinilai tidak efektif dalam mencegah penularan virus COVID-19.

Berdasarkan pengujian hubungan antara variabel praktik cuci tangan pakai sabun dengan variabel kejadian COVID-19 menggunakan uji chi square, didapatkan hasil sebagai berikut (Tabel 7)

Tabel 7. Hubungan Praktik Cuci Tangan Pakai Sabun dengan Kejadian Terinfeksi COVID-19

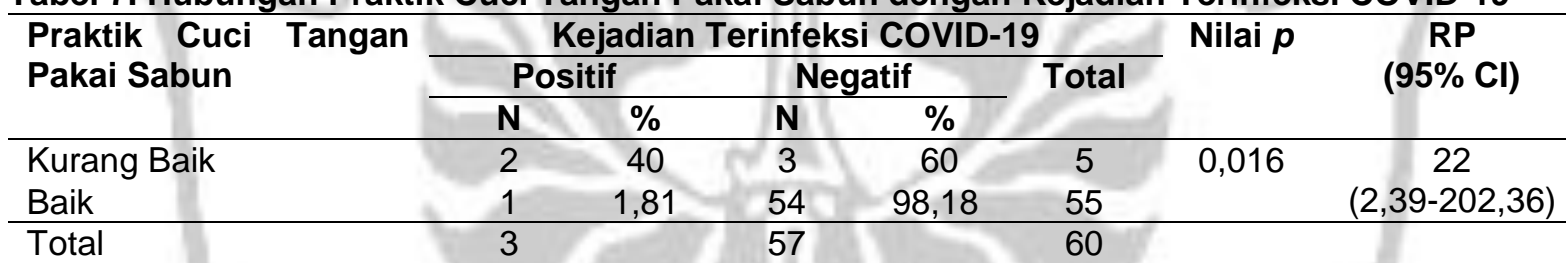

Berdasarkan hasil uji statistik antara variabel praktik cuci tangan pakai sabun dan kejadian terinfeksi COVID-19 diperoleh pvalue $=0,016$ artinya ada hubungan antara praktik penggunaan masker karyawan dan kejadian terinfeksi COVID-19. Nilai Cl 22 yang berarti karyawan dengan praktik cuci tangan pakai sabun yang kurang baik memiliki peluang resiko 22 kali untuk terinfeksi COVID19 dibandingkan dengan karyawan dengan praktik cuci tangan pakai sabun yang baik

Hasil penelitian ini sejalan dengan penelitian N Manikandan (7) yang menyatakan bahwa mencuci tangan menggunakan sabun efektif dalam mencegah penularan COVID-19 melalui kontak tidak langsung. Banyak hal yang mempengaruhi praktik cuci tangan pakai sabun dengan kejadian COVID-19, salah satunya ketersediaan sarana dan prasarana yang tersedia di lingkungan kantor.

Berdasarkan pengujian hubungan antara variabel menjaga jarak dengan variabel kejadian COVID-19 menggunakan uji chi square, didapatkan hasil sebagai berikut (Tabel 8)

Tabel 8. Hubungan Praktik Menjaga Jarak dengan Kejadian Terinfeksi COVID-19

\begin{tabular}{|c|c|c|c|c|c|c|c|}
\hline \multirow[t]{3}{*}{ Praktik Menjaga Jarak } & \multicolumn{5}{|c|}{ Kejadian COVID-19 } & \multirow[t]{3}{*}{ Nilai $p$} & \multirow{3}{*}{$\begin{array}{c}\mathbf{R P} \\
(95 \% \mathrm{Cl})\end{array}$} \\
\hline & \multicolumn{2}{|c|}{ Positif } & \multicolumn{2}{|c|}{ Negatif } & \multirow[t]{2}{*}{ Total } & & \\
\hline & $\mathbf{N}$ & $\%$ & $\mathbf{N}$ & $\%$ & & & \\
\hline Kurang Baik & 1 & 14,28 & 6 & 85,71 & 7 & 0,315 & 3,78 \\
\hline Baik & 2 & 3,77 & 51 & 96,22 & 53 & & $(0,39-36,54)$ \\
\hline Total & 3 & & 57 & & 60 & & \\
\hline $\begin{array}{l}\text { Berdasarkan ha } \\
\text { variabel menjaga jarak } \\
\text { COVID-19 diperoleh }\end{array}$ & sta & $\begin{array}{l}\text { antara } \\
\text { erinfeks } \\
\text { artinya }\end{array}$ & & $\begin{array}{l}\text { k ada } \\
\text { k karya }\end{array}$ & uns & & $\begin{array}{l}\text { kktik menjaga } \\
\text { feksi COVID }\end{array}$ \\
\hline
\end{tabular}




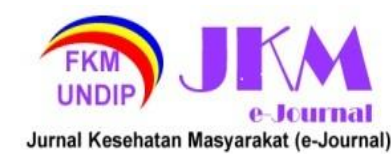

Hasil penelitian ini tidak sejalan dengan penelitian Tran Phuoc Bao Thu (8) menunjukkan bahwa kurang dari sebulan menjaga jarak secara ketat, banyak negara yang kasus positif COVID-19 berkurang drastis.. Walau tidak memiliki hubungan signifikan, belum tentu praktik menjaga jarak sepenuhnya tidak berhubungan dengan kejadian COVID-19. Dari 53 karyawan yang memiliki praktik menjaga jarak baik, terdapat 2 karyawan yang positif terinfeksi COVID-19. Hal ini dikarenakan kejadian terinfeksi COVID19 dapat dipengaruhi oleh beberapa faktor lain. Menjaga jarak terbukti dapat menurunkan probabilitas penularan COVID-19 dan merupakan protokol kesehatan yang dianjurkan WHO dan Pemerintah Indonesia. Oleh karena itu, praktik menjaga jarak harus tetap dilaksanakan oleh karyawan, baik di lingkungan kantor maupun di lingkungan luar kantor.

Berdasarkan pengujian hubungan antara variabel tidak menyentuh wajah sebelum mencuci tangan dengan variabel kejadian COVID-19 menggunakan uji chi square, didapatkan hasil sebagai berikut (Tabel 9)

Tabel 9. Hubungan Praktik Tidak Menyentuh Wajah Sebelum Mencuci Tangan dengan Kejadian Terinfeksi COVID-19

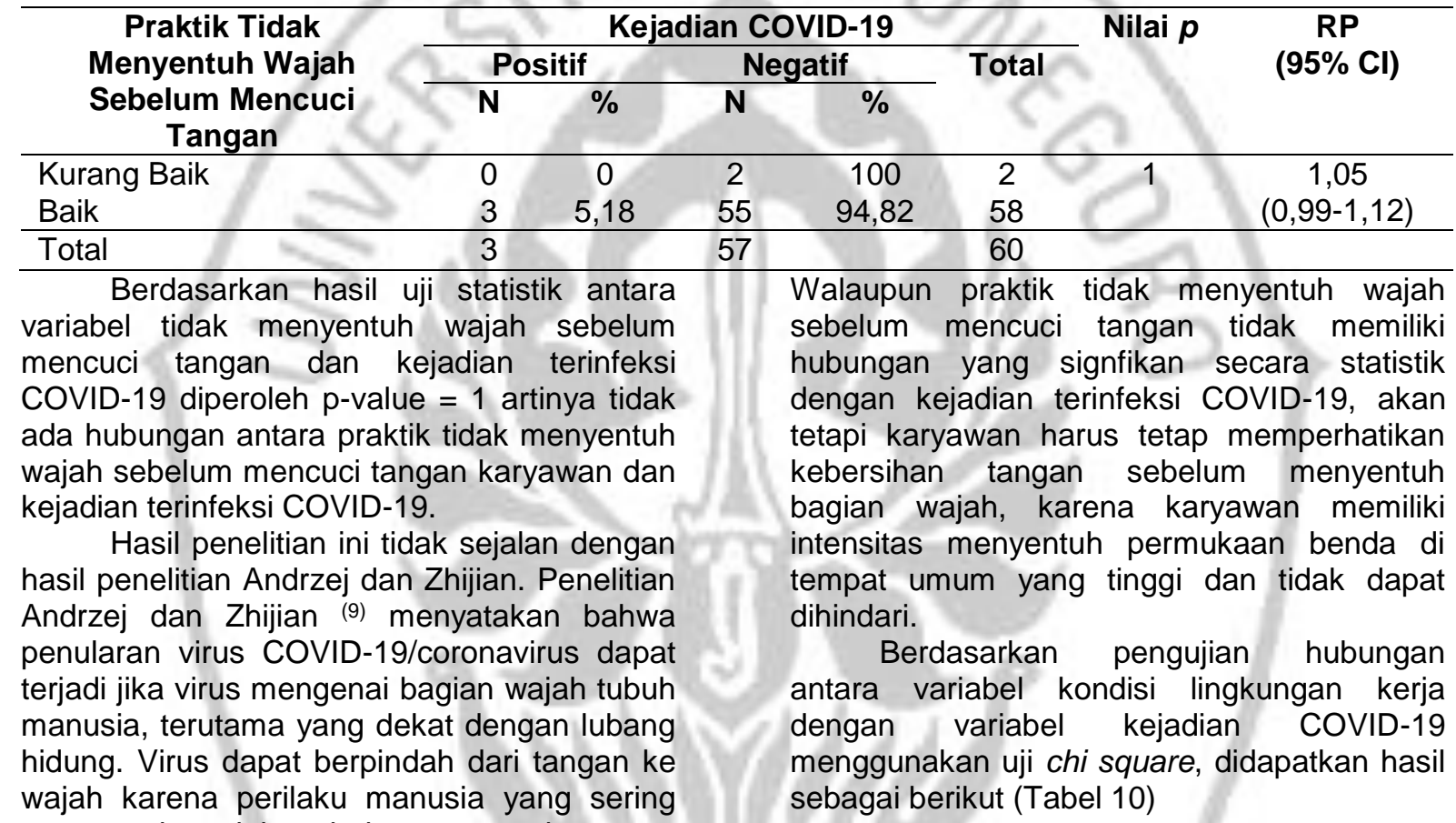
menyentuh wajah sebelum mencuci tangan.

Tabel 10. Hubungan Kondisi Lingkungan Kerja dengan Kejadian Terinfeksi COVID-19

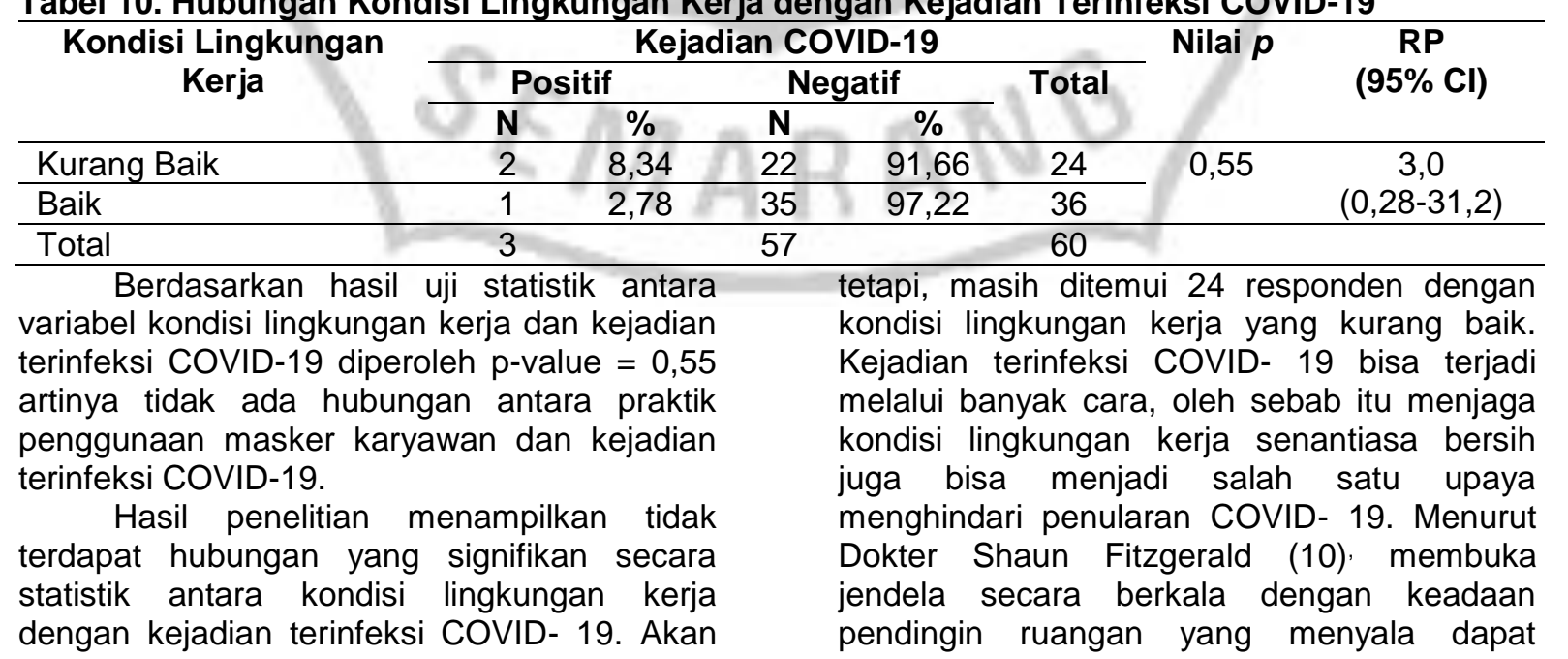




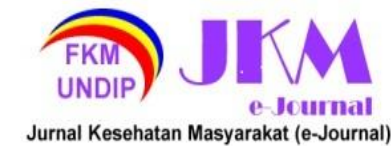

menjadi cara terbaik kurangi resiko penularan COVID- 19, hal ini disebabkan penggunaan pendingin ruangan meningkatkan resiko udara tidak tersirkulasi dengan baik sehingga meningkatkan resiko penularan COVID- 19 bila berada dalam satu ruangan dengan orang yang terinfeksi COVID- 19, sekalipun orang yang terinfeksi COVID- 19 tanpa gejala.

\section{KESIMPULAN}

Tidak ada hubungan yang signifikan antara praktik menjaga jarak $(0,315)$, praktik tidak menyentuh wajah sebelum mencuci tangan (1) dan kondisi lingkungan kerja $(0,55)$ dengan kejadian terinfeksi COVID-19 di PT X Jakarta Barat. Ada hubungan yang signifikan antara praktik penggunaan masker $(0,016)$ dan praktik cuci tangan pakai sabun $(0,016)$ dengan kejadian terinfeksi COVID-19 di PT X Jakarta Barat.

\section{SARAN}

Perusahaan dinilai perlu menyediakan masker yang lebih efektif dalam pencegahan penularan COVID-19 dan memberikan edukasi secara berkelanjutan mengenai praktik kebersihan perorangan. Karyawan sebaiknya memperhatikan jenis masker, praktik cuci tangan pakai sabun dan tetap melaksanakan praktik social distancing dan praktik tidak menyentuh wajah sebelum mencuci tangan sesuai dengan anjuran.

\section{DAFTAR PUSTAKA}

1. Yu C, Lei Q, Li W, Wang X, Li W, Liu W. Epidemiological and clinical characteristics of 1663 hospitalized patients infected with COVID-19 in Wuhan, China: a single-center experience. J Infect Public Health [Internet]. 2020;13(9):1202-9.

2. Rothan HA, Byrareddy SN. The epidemiology and pathogenesis of coronavirus disease (COVID-19) outbreak. J Autoimmun [Internet]. 2020;109(February):102433.

3. Ghosh A, Colling R. An overview of COVID-19 for diagnostic pathologists: clinicopathological correlation and diagnostic techniques. Diagnostic Histopathol [Internet]. 2020;

4. Das SK. The Pathophysiology, Diagnosis and Treatment of Corona Virus Disease 2019 (COVID-19). Indian $\mathrm{J}$ Clin Biochem [Internet]. 2020;35(4):385-96.

5. Rahman HS, Aziz MS, Hussein RH, Othman HH, Salih Omer SH, Khalid ES, et al. The transmission modes and sources of COVID-19: A systematic review. Int J Surg Open [Internet]. 2020;(September):1-12.

6. Li Y, Liang M, Gao L, Ayaz Ahmed M, Uy JP, Cheng $C$, et al. Face masks to prevent transmission of COVID-19: A systematic review and meta-analysis. Am J Infect Control [Internet]. 2020;000.

7. Manikandan N. Are social distancing, hand washing and wearing masks appropriate measures to mitigate transmission of COVID-19? Vacunas (English Ed [Internet]. 2020;21(2):1367.

8. Thu TPB, Ngoc PNH, Hai NM, Tuan LA. Effect of the social distancing measures on the spread of COVID-19 in 10 highly infected countries. Sci Total Environ [Internet]. 2020;742:140430.

9. Przekwas A, Chen Z. Washing hands and the face may reduce COVID-19 infection. Med Hypotheses [Internet]. 2020;144(August):110261.

10. Michael Harley. Experts say turn OFF air conditioning to reduce risk of virus spread. 2020. 